\title{
REGULAĈ̃O E ORGANIZAC̄̃̃ DO TRABALHO DOS TÉCNICOS DE PALCO NO CAMPO DA PRODUÇÃO CULTURAL
}

\author{
Maria Aparecida Alves*
}

\begin{abstract}
O objetivo deste artigo é analisar as formas de contratação e de regulação do trabalho dos técnicos de palco vinculados ao Theatro Municipal de São Paulo, bem como as formas de organização desse processo de trabalho, que englobam diversas modalidades de espetáculos. As equipes técnicas são compostas por profissionais das áreas de produção, iluminação, cenotécnica, maquinária, sonoplastia, guarda-roupa e contrarregragem. Metodologicamente, o estudo baseia-se em uma pesquisa qualitativa, privilegiando entrevistas abertas e em profundidade e observação de campo. A construção dos dados empíricos da pesquisa partiu dos depoimentos orais dos trabalhadores da área de apoio técnico, de suas chefias diretas e de outros profissionais. Esses dados foram corroborados por pesquisa bibliográfica e documental em bibliotecas, centros de pesquisa e órgãos públicos. Os resultados do estudo revelam que, naquele espaço de trabalho, houve redução dos vínculos contratuais estáveis, expansão das formas temporárias de trabalho e precarização do trabalho técnico.

Palavras-Chave: Trabalho técnico. Relação de trabalho. Precarização. Organização do trabalho.
\end{abstract}

\section{INTRODUÇÃO}

O presente artigo tem como objetivo analisar as formas de assalariamento a que são submetidos os técnicos de palco vinculados ao Theatro Municipal de São Paulo, com foco nos vínculos contratuais e nas formas de organização do trabalho. Os técnicos de apoio aos espetáculos desenvolvem um trabalho baseado em um saber fazer muito peculiar, pois a produção cultural do Theatro Municipal é bastante diversificada e exige criatividade para o exercício desse ofício. Nesse sentido, o trabalho de apoio técnico é parte da constituição coletiva do trabalho de produção dos espetáculos. A singularidade desse trabalho é a de criar as condições concretas para a realização dos espetáculos. Portanto, como ofício ligado ao campo cultural, suas atividades são diferenciadas das pertinentes a outras profissões que se inserem no mundo do trabalho. Mas, contraditoriamente, os

\footnotetext{
* Doutora em Educação. Professora do Departamento de Educação da Universidade Federal Fluminense.

Av. do Trabalhador, 179. Jacuecanga. Cep: 23905-000 Angra dos Reis, RJ - Brasil mcidalves@ig.com.br
}

técnicos de palco são submetidos às mesmas condições precárias de trabalho observadas em setores da iniciativa privada.

No Brasil, entre as décadas de 1980 e 1990, as empresas capitalistas iniciaram um processo de racionalização produtiva que, segundo Dedecca (1999), tinha por finalidade obter maior flexibilidade na utilização do capital e do trabalho, visando à redução de custos. Para atingir esse objetivo, as empresas alteraram o padrão das relações de trabalho estabelecidas até então, de modo a flexibilizar o uso do trabalho, alterando a forma de gestão e de uso do tempo de trabalho e, sobretudo, as regras e normas de determinação dos salários (Dedecca, 1999). Observamos que, especialmente a partir dos anos 1990, as formas de precarização do trabalho se diversificaram, com drástica redução dos direitos sociais e de garantias trabalhistas. Nesse contexto, o Theatro Municipal de São Paulo, mesmo sendo uma instituição pública, também passou a adotar novas práticas em seu processo de produção cultural, dentre elas a introdução das terceirizações, buscando racionalizar o trabalho através de formas mais flexíveis de organiza- 
ção dos espetáculos. E, além disso, criou novos modos de gestão dos contratos de trabalho, ampliando os contratos por prestação de serviços na área de apoio técnico e também as contratações temporárias por projetos, ampliando, dessa forma, as modalidades de inserção precária na profissão de técnico de espetáculos.

Com base em Williams (2000), podemos afirmar que o estudo das relações sociais no campo da cultura deve referir-se ao movimento mais geral relativo às relações sociais do modo de produção capitalista. Para o autor, numa economia de mercado, as instituições culturais, por seu grau de integração com outras instituições produtivas, passaram a fazer parte da organização social e econômica global. Assim sendo, salientamos que o campo da produção cultural tem sido estruturado a partir de critérios influenciados pelas leis de mercado, já que a iniciativa privada, em parceria com o Estado, tem ampliado as formas de investimento nas atividades culturais. Com a política de renúncia fiscal em favor do empresariado, é através do financiamento público que o Estado permite a interferência do setor privado no campo da cultura e o uso de dinheiro público investido em marketing empresarial (Wu, 2006; Magaldi, 2003).

O Theatro Municipal de São Paulo, inaugurado em 1911, é uma instituição pública vinculada à Prefeitura Municipal de São Paulo. Porém, atualmente, apesar de o teatro ser subsidiado por recursos públicos, é através da participação de recursos privados, obtidos por meio de leis de incentivo fiscal e de parcerias, que tem sido viabilizada a produção de seus espetáculos. A partir dos anos de 1990, tanto na esfera federal quanto na estadual e na municipal, houve um redirecionamento das formas de financiamento público para a área da cultura, passando a predominar o uso de incentivos indiretos via captação de recursos em empresas públicas e privadas. Desse modo, recorre-se à iniciativa privada para viabilizar as montagens dos espetáculos realizadas no teatro, submetendo-as à lógica externa de aprovação dos projetos, fato que ultrapassa o âmbito público. Essa parceria possibilita que a lógica do mercado, predominante no setor priva- do, passe a interferir tanto nas formas de contratação dos profissionais que atuam na instituição como também na forma de gerir a produção de seus espetáculos.

Nesse sentido, é importante ressaltar que o campo cultural insere-se em um processo mais amplo de redefinição das políticas públicas, em que áreas de interesse público, como é o caso da cultura, deixam de ser diretamente financiadas pelo setor público, criando-se outros mecanismos de captação de recursos para atender às demandas desse setor. Essas ações tomadas no âmbito da esfera pública podem ser caracterizadas como decorrentes das mudanças observadas no contexto social, político e econômico dos anos 1990, marcado pela retomada dos princípios neoliberais, pela adoção de práticas de livre mercado e pela reforma política e administrativa do Estado brasileiro.

Desse modo, podemos inferir que as formas de assalariamento a que são submetidos os técnicos de palco do Theatro Municipal de São Paulo fazem parte de uma conjuntura de precarização do trabalho no campo da produção cultural, que decorre de um contexto mais amplo de mudanças em vários campos, como vimos acima. Assim sendo, o estudo do trabalho na área técnica deve ser pensado nesse contexto dinâmico e contraditório, que se impõe nas formas de contratação e regulação do trabalho dos técnicos de palco, e no qual as formas tradicionais de organização dos espetáculos são ameaçadas pelas práticas de livre mercado.

Vale destacar que, para compreender o contexto vivenciado por esses trabalhadores, o nosso estudo baseia-se em uma pesquisa qualitativa, privilegiando entrevistas abertas e em profundidade, e observação de campo, tendo sido realizadas 27 entrevistas entre os anos de 2004 e 2007. Os técnicos de palco compõem as equipes de apoio técnico que se inter-relacionam com os músicos e bailarinos na concretização das apresentações artísticas realizadas no Theatro Municipal de São Paulo.

Em período recente, do segundo semestre de 2008 ao primeiro semestre de 2011, o Theatro Municipal esteve fechado para reforma do palco e restauro do prédio. Em função disso, foram 
suspensos os tradicionais concertos e as temporadas de óperas. Além disso, o cargo de direção artística do Theatro ficou vago em vários momentos desse período de fechamento.

Nesse momento de desmobilização dos trabalhadores técnicos, o poder público municipal aprovou, no ano de 2011, a criação da Fundação Theatro Municipal de São Paulo, habilitada para entrar em funcionamento a partir de 2012, visando a dar maior agilidade aos processos decisórios relativos à produção cultural. A fundação foi criada para realizar a captação de recursos no âmbito externo, promover as atividades do teatro e, sobretudo, ser responsável pela contratação de artistas e técnicos para a realização dos espetáculos.

Tendo em vista essa contextualização inicial sobre a atual situação vivenciada pelo Theatro Municipal de São Paulo, dividimos o presente artigo em duas partes, com foco na análise do trabalho dos técnicos de palco. Na primeira parte, fazemos uma análise das especificidades das relações de trabalho que são estabelecidas entre o Theatro Municipal e os técnicos de palco, bem como das formas precárias do trabalho na área de apoio técnico aos espetáculos. Já na segunda parte do artigo, descrevemos as formas de organização do processo de trabalho das equipes de apoio técnico aos espetáculos. Por fim, fazemos algumas considerações conclusivas.

\section{FORMAS DE ASSALARIAMENTOE PRECARIZAÇÃO DO TRABALHO NA ÁREA DE APOIO TÉCNICO}

Como fenômeno recente, a partir dos anos 1990, notamos que tem havido uma intensificação das diversas formas de precarização do trabalho, as quais também podem ser observadas no Theatro Municipal de São Paulo, que optou por racionalizar o trabalho na área de apoio técnico aos espetáculos. Como reflexo dessa situação, observamos uma intensa precarização das relações de trabalho a que são submetidos os profissionais que fazem parte das equipes internas de apoio técnico, com- postas por 44 profissionais das áreas de produção, iluminação, cenotécnica, maquinaria, sonoplastia, guarda-roupa e contrarregragem.

Para compreender o contexto de mudanças nas formas de contratação dos técnicos de palco do Theatro Municipal de São Paulo, faremos uma breve retrospectiva da história recente desses cargos de natureza técnica, criados exclusivamente para dar suporte às atividades artísticas. Até os anos de 1970, havia poucos registros oficiais a respeito da composição de uma equipe técnica permanente voltada ao apoio artístico. Alguns desses cargos tinham acesso assegurado através de concurso público de títulos e provas ${ }^{1}$, possibilitando estabilidade plena no emprego. A criação do Quadro de Atividades Artísticas ${ }^{2}$ vinculado ao Theatro Municipal de São Paulo se deu através da Lei Municipal $n^{\circ}$ 8.401, de 08/06/1976, que regulamentou a contratação de pessoal para a área de apoio técnico aos espetáculos, prevendo a ampliação dos cargos já existentes e a formação de equipes completas que pudessem dar assistência em todas as modalidades de espetáculos.

Posteriormente, com o objetivo de regulamentar essa lei, foi promulgada a Lei Municipal $\mathrm{n}^{\circ}$ 9.168, de 04/12/1980, que previa duas formas de contratação de pessoal para a composição básica dos órgãos de apoio, que são contratação mediante admissão ${ }^{3}$ ou contratação para prestação de serviços técnicos especializados por prazo determinado. Essa Lei n ${ }^{\circ} 9.168$ ganha sentido se for pensada em termos de adequação às determinações da Lei Federal n ${ }^{\circ} 6.533$, de 24/05/1978, que reconhe-

${ }^{1}$ A primeira referência à criação de cargos técnicos vinculados às atividades artísticas pode ser encontrada na Lei Municipal no 3.829, de 28/12/1949, que oficializa a Orquestra Sinfônica Municipal. Esses cargos também foram citados no Decreto Municipal no 7.895 promulgado em 1969, e na Lei Municipal no 8.183 promulgada em 1974, como parte integrante do funcionalismo público. ${ }^{2} \mathrm{O}$ Quadro de Atividades Artísticas é composto por seis Corpos Artísticos, que são: a Orquestra Sinfônica Municipal, a Orquestra Experimental de Repertório, o Coral Paulistano, o Coral Lírico, o Quarteto de Cordas e o Balé da Cidade de São Paulo, e engloba todos os trabalhadores das equipes de apoio técnico.

${ }^{3}$ A Lei 9.160/1980 "[...] institui o regime jurídico dos servidores admitidos em serviço de caráter temporário e contratados para funções de natureza técnica especializada”. Os trabalhadores contratados sob o regime de Admissão adquiriram estabilidade no emprego com a promulgação da Constituição Federal de 1988. 
ce oficialmente artistas e técnicos de espetáculos como trabalhadores de um campo profissional específico e, portanto, detentores de direitos sociais vinculados ao trabalho. Porém, em menos de um ano, foi decretada uma nova Lei Municipal $n^{\circ}$ 9.320, de 15/09/1981, que altera as leis anteriores e define novas formas de inserção nos cargos técnicos na área de apoio aos espetáculos, através da nomeação para cargos em comissão, condição que não assegura estabilidade alguma no emprego. E, em relação aos cargos de técnicos estáveis existentes nas décadas passadas, eles vão sendo gradativamente extintos à medida que vão vagando.

Dessa forma, podemos observar que, a partir dos anos de 1980, o Theatro Municipal de São Paulo passa a adotar uma nova prática nas contratações. Ao mesmo tempo em que houve a ampliação dos cargos na área de apoio técnico, também ocorreu a perda da estabilidade no emprego para a grande maioria desses trabalhadores. Portanto, identificamos que, a partir do momento em que se reconhece a especificidade do trabalho técnico - que é a de criar as condições concretas para a realização do espetáculo-, e se estabelece que esses profissionais devem estar vinculados à área artística, eles passam a ser diferenciados do restante do funcionalismo público, perdendo a antiga estabilidade.

Notamos que, nos anos de 1990, as contratações se estabilizaram, passando a haver redução das contratações de técnicos de palco. A maior parte dos cargos estáveis foi extinta por ocasião das aposentadorias, transferências para outros setores ou demissão, passando a haver apenas reposição parcial desses técnicos, sendo que os novos contratados passaram a se inserir em cargos em comissão.

Portanto, dentre as práticas de racionalização do trabalho na área de apoio técnico aos espetáculos, o Theatro Municipal optou pela redução do quadro funcional técnico ligado às atividades artísticas, já que eliminou os mecanismos legais para a realização de concurso público para inserção nessa área, e os cargos existentes passaram a ser preenchidos através de cargos em comissão. Essa situação não garante estabilidade, devendo o trabalhador permanecer no cargo até o momento em que haja interesse da Administração Pública, que pode exonerar esses técnicos a qualquer momento.

Ressaltamos que, a partir dos anos 1990, o Theatro Municipal de São Paulo passou a adotar três formas de contratação de trabalhadores na área de apoio técnico: a primeira delas é na condição de cargo em comissão, remunerado através da verba de pagamento do funcionalismo público; a segunda se dá através da prestação de serviços por intermédio de "Verbas de Terceiros", ${ }_{4}^{4}$ que remunera os profissionais que prestam serviços na área da cultura em caráter temporário, com contratos renovados a cada 6 meses; e a última forma são os contratos temporários para as temporadas de óperas. Lembramos que nenhuma delas assegura a estabilidade no emprego.

Até a década de 2010, dos 44 profissionais técnicos vinculados ao Theatro Municipal, apenas 12 eram enquadrados no antigo regime: 1 era efetivo no cargo de conferente de palco, 1 era admitido no cargo de iluminador, e 10 costureiras-camareiras eram admitidas, sendo que todos esses cargos seriam extintos por ocasião das aposentadorias. Em casos de reposição desses funcionários, os novos contratados passavam a ocupar cargos em comissão, ou alguma outra forma de contratação precária. Dos 32 restantes, 29 estavam inseridos em cargos em comissão e 3 estavam vinculados ao Balé da Cidade como prestadores de serviços, com contratos renovados permanentemente a cada seis meses. Esse número variava de acordo com a intensidade das atividades artísticas. Ressaltamos que essas práticas revelavam a precariedade dos cargos ligados à área técnica do Theatro Municipal.

A situação dos trabalhadores permanentes, ocupantes de cargos em comissão, também não caracterizou vínculos estáveis de trabalho. Conforme o trecho abaixo, a instabilidade era constante:

São todos cargos em comissão. É o seguinte, eles estão aí; uma suposição, entra uma chefia, um

\footnotetext{
"Verbas de Terceiros" é uma verba específica para pagamento de contratos de prestação de serviços firmados entre o Theatro Municipal e os profissionais das áreas técnica e artística que, apesar de serem contratos temporários, são prolongados indefinidamente através de constantes renovações.
} 
deles discute com o chefe, o chefe novo que entra fala: eu não quero mais o teu serviço, você está exonerado. $\mathrm{O}$ cara pode ter 10 anos, 15 anos, 20 anos de teatro, ele sai sem direito a nada, ele não tem direito a fundo de garantia, ele não tem direito a nada, nada, ele vai receber o equivalente até aquele dia que ele trabalhou e acabou e não tem mais nada. (Chefe de palco, 01/10/2004).

Esses profissionais permaneciam no cargo de acordo com a necessidade do setor de cenotécnica, mas a coordenação ${ }^{5}$ desse setor é nomeada a cada nova gestão da direção artística do Theatro Municipal, que, por sua vez, é substituída a cada quatro anos com a mudança do cargo de prefeito municipal. Então, a cada quatro anos, quando ocorre a eleição municipal, acontecem novas nomeações, o que sempre gera um clima de muita instabilidade entre os trabalhadores da área técnica.

Também a contratação de trabalhadores que pertencem ao quadro permanente, como prestadores de serviços, através de "Verba de Terceiros", possibilitava apenas vínculos temporários de trabalho, já que os contratos eram renovados a cada seis meses e estavam sempre na dependência da liberação anual de dotação orçamentária para atender a essa finalidade.

Apesar de serem contratos para prestação de serviços renovados a cada 6 meses, esses cargos estavam vagos e poderiam ser ocupados permanentemente. Mas a Administração Pública optou por não ampliar o quadro de profissionais permanentes. Alguns técnicos vivenciavam a situação de renovação de contratos há mais de 10 anos. O sonoplasta, contratado através de "Verba de Terceiros”, comenta essa situação:

Não somos funcionários públicos concursados, nós somos contratados, nós estamos esperando sair concursos; já faz mais de 12 anos que não sai concursos. [...] A gente assina contratos semestrais. E sempre que muda a gestão, que vai entrar outro prefeito, a gente tem que disponibilizar o nosso cargo (Sonoplasta do Balé, 23/11/2006).

Os técnicos contratados através de "Verba de Terceiros” recebiam um salário prefixado nos con-

${ }^{5}$ Observamos que, no período entre 2005 e 2006, tinham passado pela coordenadoria de cenotécnica três profissionais diferentes. tratos semestrais, o que caracterizava trabalho assalariado sem registro em carteira. Eles eram contratados “[...] à margem da regulamentação do mercado de trabalho, à margem das regras dos contratos por tempo indeterminado e em tempo integral e da organização sindical.” (Cacciamali, 2000, p.166).

Além disso, o Theatro Municipal, para realizar as produções dos espetáculos, mediante a não reposição do quadro funcional permanente, passou a ampliar as formas de contratação de técnicos de palco temporários para cobrirem as temporadas de ópera. Essa prática pode ser observada no depoimento abaixo:

Na época de ópera, a gente tem que contratar mais gente, a equipe do Theatro do dia a dia é pequena. Aí eu contrato 5 maquinistas, 2 contrarregras, 4 contrarregras, dependendo da necessidade, aí eu vou vendo essas pessoas, como é que elas trabalham. Como que é o desempenho delas, se elas têm futuro para área, entendeu? Aí a gente chama, ele vai trabalhando aí, a gente vai fazendo um teste com ele, entendeu? (Chefe de palco, 29/11/2006).

Essas contratações temporárias circunstanciais, para atender a projetos individuais, são bastante praticadas para suprir as necessidades das temporadas de ópera, pois, apesar de esses profissionais exercerem um ofício específico na área de apoio técnico, eles são remunerados informalmente, como se atuassem como figurantes. Viabilizam-se essas contratações para atender a cada projeto individualmente, sendo que esses trabalhadores permanecem no Theatro apenas durante as temporadas de ópera, de 2 a 4 meses, envolvendo desde a preparação, montagem até a realização dos espetáculos.

Entre esses trabalhadores temporários, vinculados ao Theatro Municipal de São Paulo por projetos individuais, existem aqueles com algum conhecimento profissional na área de apoio técnico, os quais são recorrentemente chamados para cobrir as temporadas de ópera. E há, ainda, aqueles que eventualmente permanecem sem trabalho e desenvolvem essas atividades temporariamente, praticando os chamados bicos.

Ao analisar as condições de trabalho a que são submetidos, podemos afirmar que esses traba- 
lhadores vivem em condições extremamente precárias, pois grande parte deles não contribui com a previdência social e, portanto, não tem direito à aposentadoria, ao Fundo de Garantia por Tempo de Serviço, ao auxílio-doença. Se ficarem doentes, são forçados a parar de trabalhar, perdendo integralmente sua fonte de renda. Nos dias de montagens, ensaios e realização dos espetáculos, eles não têm horário fixo de trabalho, tendo jornadas superiores a 8 horas diárias.

\section{Formas de terceirização das atividades de apoio técnico aos espetáculos}

Como parte das estratégias de racionalização do trabalho na área de apoio técnico do Theatro Municipal, a partir da segunda metade da década de 1990, passou-se a priorizar a contratação de profissionais por projetos individuais para realizar os trabalhos relativos à criação artística, fato que estimulou a ampliação das terceirizações. Esse mecanismo permitia ao Theatro transferir a responsabilidade da contratação e manutenção de profissionais da área técnica para os ateliês particulares, que se responsabilizam pela criação e confecção de todo o material utilizado nos espetáculos. Dessa forma, a instituição não necessitaria ampliar seu quadro de profissionais das equipes de apoio técnico.

Desse modo, eram admitidos profissionais externos, contratados por projetos individuais, que vinham cobrir as temporadas de óperas, ficando essas contratações sob a responsabilidade do Diretor Artístico do espetáculo, e se estendiam desde sua preparação atéa finalização. Essa forma de vinculação se dava através da terceirização dos trabalhos mais ligados à área de criação artística e confecção de cenários, de figurinos e de adereços. Nesse caso, eles eram contratados para prestação de serviços. Podemos observar como se dava esse mecanismo através do relato de um cenógrafo-figurinista, contratado por projeto pelo Theatro (13/12/2006):

O Theatro contrata o trabalho dentro de um bloco de coisas para serem feitas, não é? Ou ele pode isolar, porque o cenotécnico pode ser contratado separado, então você tem um produtor. A gente pode pegar um bloco, o Theatro pode chegar aqui e falar: eu quero esse cenário. O cenário tem tudo isso. Eu vou cuidar desde a fechadura até [...] A única coisa que a gente sempre fala: eu não faço luz, eu não faço som e não fazemos a parte elétrica.

Notamos que, dentro da contratação desse cenógrafo, cabia ainda a subcontratação de outros profissionais para realizar trabalhos que não faziam parte da atividade-fim desse ateliê. Então, havia uma reorganização do processo de produção relativo às atividades artísticas, como podemos ver:

\begin{abstract}
Então, isso a gente não assume, a parte robótica, essas coisas. Mas, se for o caso, a gente terceiriza. Se eles falarem: não, a gente quer que vocês cuidem de tudo. A gente terceiriza. E a gente se responsabiliza por aquilo. A empresa se responsabiliza, então todo mundo trabalha pela minha empresa que está trabalhando para o Theatro. Então, por exemplo, eu te contrato para fazer a robótica de tal espetáculo, você vai prestar contas comigo para eu prestar contas ao Theatro (Cenógrafo, 13/12/2006).
\end{abstract}

Ressaltamos que os ateliês contratavam pessoal temporário para realizar trabalhos na área artística, conforme expõe o cenógrafo contratado por projeto (13/12/2006):

Não, a casa tem 3 funcionários fixos e 3 sócios. Aí a gente vai aglomerando conforme a necessidade, porque não dá para você manter um bonequeiro se você vai fazer um boneco só durante o ano inteiro. Não vai ficar um bonequeiro aqui, de braços cruzados. Não vai ficar uma costureira aqui, de braços cruzados, esperando chegar [...]

As ações adotadas pelo Theatro Municipal abriam espaço para um processo de terceirização que se dava em cadeia. Como os ateliês subcontratados não possuíam uma estrutura funcional permanente, eles também terceirizavam seus trabalhos. Eo Theatro, por sua vez, somente contratava profissionais externos por projetos individuais, mediante a existência de verba obtida através da captação de recursos, e, assim, buscava reduzir ao máximo os riscos advindos desse tipo de produção.

Outro aspecto observado em relação às terceirizações é que, devido à necessidade crescente de trabalhos variados para atender às necessi- 
dades do mercado de produção artística, esses ateliês correm o risco de perder o foco do campo artístico - que estaria mais centralizado na realização de trabalhos criativos concebidos artesanalmente -, voltando-se para a realização de trabalhos que atendam ao maior número possível de demandas. O depoimento de um cenógrafo (13/12/2006) confirma essa tendência:

Mas aí eu vou ter que ter uma administração de funcionários... Porque aí vou ter que começar a aumentar, eu vou ter que ter sempre serviço para o serralheiro; eu vou ter que começar a ter sempre serviço para o marceneiro. Vai ter uma hora que eu vou ficar meio... Vou começar a me concentrar numa... Você não vai... Aí vai começar a marcenaria a predominar, aí você acaba.

A realidade vivida pelos técnicos de palco vinculados a teatros públicos também se estende àqueles contratados pelos ateliês particulares. $\mathrm{O}$ depoimento de um sócio de empresa de iluminação, que presta serviços para teatros públicos e privados, confirma a tendência de precarização do trabalho na área de apoio técnico, especialmente na de iluminação:

É verdade, a realidade é que o cara não tem nenhum vínculo empregatício, ele entra na empresa, trabalha, trabalha, sai da empresa. Algumas pessoas pagam ele direitinho, os direitos dele, outras não pagam. Trabalha-se muito com free lancer, muito, muito, então a empresa, quando tem pouco trabalho, os free lancer param de trabalhar, param de receber.

[...] A gente já trabalha com free lancer, sim. Tem uma época em que o nosso pessoal está todo ocupado, está tudo na rua e aparece mais trabalho, você tem que atender obrigatoriamente, não é? E a gente contrata free lancer sim, tem muita gente boa... (sócio de empresa de iluminação, 29/11/2006).

Segundo um coordenador de teatro particular e iluminador (21/12/2006), as condições de trabalho são as mais adversas, pois os trabalhadores da área técnica lidam com prazos exíguos, falta de verba, contratos de trabalho e condições precárias, baixos salários, falta de equipamento. Porém, paradoxalmente, é fundamental para esses trabalhadores a busca de novos conhecimentos e a dedicação, conforme expõe um iluminador:
Iluminação, porque o que que é? 2, 4, 5 anos para um técnico é muito pouco; para ele conhecer o mínimo possível, precisa de muito mais. Isso eu falo de experiência, que às vezes a gente fala: eu tenho pessoas que trabalham comigo há tantos anos e tem momento que a pessoa ainda está meio... Não é? Meio cru, digamos assim, porque tem que ter uma série de coisas que se somam para dizer que é iluminador. Eu tenho que ter disciplina, sabe? Ética, saber... Saber a relação interpessoal, conversar com as pessoas, entender o que o diretor quer, ele tem que estudar bastante, ele tem que entender um pouco de geografia, de física e uma série de coisas (Iluminador, 21/12/2006).

Há também o depoimento de uma iluminadora (23/11/2006), que expõe as condições de trabalho a que são submetidos os técnicos de teatro no início de suas carreiras:

No teatro é bem forte, os grupos não têm verba. Aí eles vão contratar uma pessoa que eles podem pagar, ou, às vezes, nem conseguem pagar. [...] Aí você vem como quase todo mundo, estagiário, sem ganhar um tostão. Ganha um vale coxinha, que é para a alimentação, e vale transporte, às vezes não ganha nada disso, mas você vai porque você gosta, até por isso que falam que, no começo, ninguém ganha dinheiro. Não adianta...

Diversos profissionais da área de produção cultural na cidade de São Paulo dão o relato das condições de trabalho a que são submetidos os técnicos vinculados à área teatral e também apontam para uma redução das ocupações nessa área, conforme podemos observar em vários depoimentos, entre eles o do sócio de empresa de iluminação $(29 / 11 / 2006)$ :

A pessoa que trabalha com iluminação, o técnico de iluminação, ele se sente massacrado diariamente. Aí, depois que ele se especializou um pouquinho, atingiu um estágio melhor, conseguiu dar mais visibilidade para a pessoa, para o trabalho dele, para a importância que ele tem, que o salário dele melhorou, aí geralmente, se ele for empregado fixo ou num teatro ou numa instituição, pode ser Sesi, Sesc, o que for, não é muito diferente também, ele vai ser mandado embora, para entrar no lugar dele alguém que é da manutenção, é da portaria, que não entende nada aqui. Então, essa é uma realidade...

E, por último, um cenógrafo (13/12/2006) dá o relato das condições de trabalho que ele ob- 
serva nas companhias teatrais,

Até hoje, por exemplo, se você pegar uma companhia que viaja, ela vai com dois técnicos. O sonoplasta, que faz sonoplastia e luz e ajuda o cenotécnico de palco, que faz a montagem de cenário, a maquinaria do cenário e, ainda por cima, é contrarregra. Quem fica no palco hoje [...] Às vezes tem companhia que viaja com um cara só. Ele monta um cenário, junto com o técnico de luz e som, porque geralmente o técnico de som faz som e luz. Ou ele é técnico de luz e faz som, porque é ligar um botão. A não ser que seja uma produção grande, em que o som seja primordial.

Para uma análise da realidade observada nos ateliês particulares, devemos levar em conta que seus proprietários são os cenógrafos, figurinistas, iluminadores, os quais prestam serviços em teatros públicos e privados, além de outras áreas do campo cultural. Para a confecção de suas criações, eles contratam outros trabalhadores como assalariados, muitas vezes sem registro em carteira, e subempregam temporariamente outros que se encaixam nas mesmas condições descritas para os técnicos contratados temporariamente pelo Theatro Municipal de São Paulo.

Constatamos, portanto, que tanto o trabalho vinculado ao Theatro Municipal de São Paulo quanto o vinculado aos teatros privados segue a tendência predominante na iniciativa privada, em que o trabalho por tempo indeterminado, considerado a forma mais estável de emprego da sociedade salarial, está perdendo hegemonia (Castel, 1998).

Com relação às mudanças recentes em termos de reestruturação das carreiras de técnicos e artistas vinculados ao Municipal, podemos destacar que, na segunda gestão do prefeito Gilberto Kassab (20092012), tendo Carlos Augusto Calil como secretário municipal de cultura da cidade de São Paulo, foi criada a Fundação Theatro Municipal de São Paulo, através do Projeto de Lei 09/2010 aprovado em 05 de maio de 2011 pela Câmara Municipal de São Paulo e implementado no ano de 2013.

A Fundação Theatro Municipal de São Paulo, sendo de direito público, continuará vinculada à Secretaria Municipal de Cultura, mas terá autonomia para atuar nos campos artístico e financeiro.
Ela receberá recursos do orçamento da Prefeitura de São Paulo, que serão complementados por outros, obtidos através da venda de produtos e de serviços educativos e culturais, da cobrança de ingressos, do patrocínio, de convênios, e de doações.

A Secretaria Municipal de Cultura alegou que uma das finalidades da criação da Fundação seria dar mais rapidez à produção dos espetáculos, de modo a agilizar a compra de materiais, de cenários e de figurinos, sem ter de se submeter aos procedimentos burocráticos. E o principal objetivo foi regularizar a contratação de artistas e técnicos para os espetáculos do Theatro, processo que se efetivou com a criação de uma Organização Social (OS), uma entidade civil sem fins lucrativos que se tornou responsável por sua gestão e pela contratação de pessoal.

Os funcionários do Theatro puderam optar por permanecer na Prefeitura de São Paulo ou serem afastados dela para se vincular à Fundação Theatro Municipal. Desse modo, a instituição pôde remanejar parte dos técnicos de palco comissionados para a Secretaria Municipal de Cultura que, por sua vez, os designou para trabalhar em outros teatros da cidade de São Paulo. Se, nas condições anteriores, não havia garantia de manutenção do trabalho, atualmente, no contexto de uma Organização Social (OS), as relações trabalhistas se tornaram ainda mais instáveis e precárias para aqueles que aderiram aos contratos de prestação de serviços. Como o Theatro passou a ser uma fundação, a questão que se colocou para os poucos técnicos de palco que adquiriram estabilidade no emprego é que, se quisessem se manter no exercício profissional, em um teatro de reconhecido prestígio, teriam de abrir mão dos vínculos permanentes para serem recontratados sob novas condições pela Organização Social.

Constata-se, assim, que a regulamentação do trabalho no Theatro Municipal tem sido marcada pela flexibilidade, cuja função acaba por ser a de ajustar o trabalhador às novas necessidades de racionalização econômica, mantendo-o disponível às flutuações da demanda. Assim, com a implementação de uma Organização Social, ape- 
nas um número restrito de trabalhadores puderam manter vínculos permanentes com a Secretaria de Cultura. Desse modo, é cada vez mais crescente, no mercado de trabalho do campo cultural, o número de contratos de trabalho por tempo determinado e de trabalho sem registro em carteira, levando um crescente número de trabalhadores para a informalidade, sem contribuir com o sistema de previdência social.

Nessa nova circunstância, o fato de o Theatro ter mantido um número reduzido de técnicos de palco sem garantia de estabilidade no emprego acabou sendo funcional à Administração Pública, tornando mais fácil o processo de gestão. Assim, quanto menor for o emaranhado de relações de assalariamento estabelecidas na área da cultura, maior será seu poder de decisão sobre manter ou extinguir o vínculo estabelecido com os profissionais da área de apoio técnico, processo que se tornou efetivo com a criação da Fundação do Theatro Municipal.

\section{ORGANIZAÇÃO DO PROCESSO DE TRABA- LHO DAS EQUIPES DE APOIO TÉCNICO AOS ESPETÁCULOS}

O Theatro Municipal de São Paulo abrange uma variedade de espetáculos, os quais envolvem a produção artística da casa e também a produção externa. Desse modo, há a exigência de que o trabalho na área de apoio técnico deva atender a essa diversidade. Nesse sentido, criou-se uma forma de organização do trabalho em que se mantém um quadro de técnicos permanentes, mesclados com outros profissionais temporários, contratados por projetos individuais e ainda subcontratados por terceiros.

Observamos que, apesar de o Municipal ter um espaço amplo, o seu uso se dá sempre de forma multifuncional, abrangendo todas as manifestações culturais, de modo a economizar custos e maximizar o lucro. Dessa forma, cabe aos trabalhadores da área técnica, que são os responsáveis pelas montagens, mobilizar todos os tipos de habilidades possíveis, para poder montar formas de espe- táculo tão diversas. ${ }^{6}$

Podemos ressaltar que, apesar de os técnicos de palco do Theatro Municipal realizarem tarefas multifuncionais, eles desenvolvem um trabalho alicerçado em um saber-fazer baseado na tradição e na ajuda mútua. Lembramos que a base desse ofício estaria em uma das formas produtivas predominantes no início da manufatura, que tinha por base a cooperação de artífices de determinados ofícios. Segundo Marx (1982, p.389), “[...] a divisão manufatureira do trabalho é uma espécie particular de cooperação, e muitas de suas vantagens decorrem não dessa forma particular, mas da natureza geral da cooperação". Posteriormente, com o avanço do sistema capitalista, a divisão social do trabalho se intensificou de modo a decompor esses ofícios em diferentes operações particulares. Portanto, é a partir da divisão do trabalho na manufatura que ocorrem profundas mudanças no processo de produção. Com a incorporação do trabalho do artífice pela manufatura que, em alguns momentos, introduz a divisão do trabalho e, em outros, combina ofícios anteriormente distintos, ele é duplamente expropriado, tendo como resultado a perda da autonomia desse trabalhador e a perda da posse dos meios de produção (Marx, 1982, p. 413-414).

Esse processo de expropriação do trabalhador também pode ser observado no campo da produção cultural, em que se desenvolve uma série de relações sociais, algumas delas relacionadas às mudanças nos meios de produção, ocasionando uma transformação na divisão do trabalho nessa área, "[...] relacionada tanto com as divisões especializadas do processo quanto com a propriedade e a gerência dos meios de produção desenvolvidos" (Williams, 2000, p. 112).

Em sua análise das mutações no processo de trabalho no campo da produção cultural, Williams (2000, p.112) ressalta que o estabelecimento de uma divisão do trabalho mais formal e ${ }^{6}$ O Theatro Municipal possui uma sala de espetáculos com 1.523 lugares; dentre as atividades internas, conta com apresentações de ópera, concertos variados (didáticos, do meio dia), vesperais líricas e apresentações do Balé da Cidade. Abrange ainda eventos externos, que variam entre óperas, balés, peças teatrais e espetáculos diversos, shows e premiações de músicos e também alguns eventos fechados ao grande público. 
organizada, com base na profissionalização e apoiada numa administração mais centralizada, ocorreu paralelamente aos avanços nos meios de produção. Além disso, esse processo foi marcado pelo surgimento das figuras de 'produtor', 'diretor' ou 'empresário', que, até o século XIX, eram precedidos pelo ator-empresário, passando-se a utilizar novas técnicas de encenação, com inovação nas áreas de cenário e de iluminação.

Segundo Williams (2000, p.113-114), essas mudanças, apesar de demarcarem uma maior divisão do trabalho, estavam mais voltadas para a redistribuição de papel e de autoridade dentro das companhias profissionais existentes. Esse autor afirma que "[...] as mudanças mais profundas só vieram com o desenvolvimento das novas tecnologias reprodutivas", o que passou a exigir uma especialização profissional muito mais ampla, conforme expõe:

Aos escritores e atores e, a seguir, aos cenógrafos, juntaram-se os operadores de câmeras, os técnicos de som, os montadores e toda uma série de pessoas com habilidades subsidiárias. [...]. Podese dizer que estes representam apenas uma evolução das formas anteriores de apoio de artífices; mas a situação geral era qualitativamente nova, de tal modo que o trabalho nessa área tornou-se indispensável, nas tecnologias avançadas, ainda que pudesse restar alguma dúvida de que esses trabalhadores realmente fizessem parte da produção cultural (Williams, 2000, p.113-114).

Segundo Menger (2005, p.60), o campo cultural, apesar de sua singularidade em relação a outros setores da economia, tem suas ações permeadas por orientações bastante contraditórias, passando a se pautar pelos princípios norteadores de "eficácia econômica" e pelos "critérios de aproveitamento". Menger (2005, p.44-45) parte da hipótese de que as atividades de criação artística, contrariamente ao que se pensa, não representam a "face oposta do trabalho", mas, sobretudo, são reivindicadas “[...] como a expressão mais avançada dos novos modos de produção e das novas relações de emprego engendradas pelas mutações recentes do capitalismo". Nesse novo contexto, a figura do artista pode ser vista como a do trabalhador inventivo ou criativo e como o prenúncio das novas configurações que se estabeleceram no mercado de trabalho.

Podemos observar que, no Theatro Municipal, há uma divisão do trabalho das diferentes equipes de apoio técnico, em que prevalecem as relações de cooperação entre as várias categorias profissionais. Mas, segundo Menger (2005), com o desenvolvimento das atividades artísticas através da produção por projetos, ou vinculadas a instituições que mesclam formas mistas de produção, isso acaba levando ao estabelecimento de outras formas hierárquicas,

[...] no interior de uma organização, com uma multiplicidade de elos contratuais temporários ou recorrentes com profissionais independentes, constituindo equipes que se juntam e se dispersam conforme as circunstâncias. Neste contexto, a divisão vertical do trabalho deixa de ter formas duráveis e disciplinares de controle e de supervisão, e uma individualização acrescida atribui a cada um uma maior autonomia e responsabilidade mais afastada de ligações acordadas (2005, p.66).

No Theatro Municipal, observamos que a divisão do trabalho é mais horizontalizada, possibilitando certa autonomia entre as diversas áreas subcontratadas e, com isso, é atribuída aos técnicos permanentes uma maior responsabilidade sobre o resultado final das produções artísticas. A eles cabe adaptar os cenários, figurinos e adereços às condições internas oferecidas pelo Theatro. Para tanto, os técnicos de palco oferecem apoio na construção e na montagem dos cenários e, a partir da finalização dessa etapa, eles passam a se responsabilizar pelo apoio técnico durante todo o espetáculo.

Na separação do trabalho de apoio técnico entre as equipes vinculadas ao Theatro e as equipes externas, há uma diferenciação dos saberes inserida nas relações estabelecidas por essas equipes. Esse teatro não tem um número suficiente de trabalhadores da área técnica para cobrir toda a sua produção. Por isso "[...], vem para o teatro, a cada produção, uma equipe grande de artesãos, de artistas plásticos, pessoas que fazem figurino, maquiadores, cenotécnicos que trabalham junto com o nosso pessoal e depois se vão." (Coordenador de óperas, 22/09/2004). 
Nos eventos internos, todavia, em que a construção dos cenários é realizada por cenógrafos e cenotécnicos subcontratados por projeto, eles oferecem seus serviços de montagem, mas seus funcionários tratam a técnica como algo voltado para si mesmo. Nesse momento, vêm ao palco marceneiros, pintores, carpinteiros que, muitas vezes, são confundidos com os próprios técnicos que cuidam das maquinarias do Theatro Municipal. Os técnicos permanentes, além de praticarem a parte técnica propriamente dita, têm de criar meios de adaptar o cenário que já vem pronto às circunstâncias internas do Theatro. Ou seja, eles buscam sanar todas as dificuldades para dar início aos ensaios e à realização dos espetáculos.

De acordo com informações dos profissionais vinculados ao Theatro Municipal, a ópera é o maior evento que ocorre dentro do teatro, exigindo muito tempo de trabalho para sua produção. Segundo informações do coordenador de ópera (22/09/2004), para a realização de um evento desse porte, depois de finalizado o trabalho de concepção e criação da obra, o trabalho de confecção, montagem, ensaio e apresentação dura, em média, um mês e meio.

Conforme observamos, enquanto é feita a escala de montagem com a coordenação de cenotécnica, a equipe permanente do Theatro prepara-se para a chegada do cenário, que será montado juntamente com a equipe externa. Assim, todas as produções internas ou externas devem comunicar à cenotécnica quais serão suas necessidades para a montagem do espetáculo. Apesar de os profissionais vinculados a essa coordenadoria terem regras internas, a coordenadora admite: “[...] a gente serve aos corpos estáveis e às companhias de fora, que vem se apresentar no Theatro Municipal" (Coordenadoria de cenotécnica, 05/11/2004).

Normalmente, qualquer espetáculo que seja, é dividido entre montagens, ensaios e apresentações; então, são três fases distintas, mas que é tudo para uma coisa só. Então, primeiro é a montagem, é o caso que está acontecendo agora; terminando-se a parte do palco, depois vai entrar a escada grande com os iluminadores, que vão mexer nos refletores, nas luzes; depois vai entrar o rapaz do som, que vai ligar as fitas gravadas e não gravadas, o som ao vivo ou som em off. Tudo isso vai acontecer. Tudo isso vai passar pelos ensaios, primeiro, segundo, terceiro ensaio, quantos se fizerem necessários e depois o ensaio geral, que é aquele que vai anteceder o espetáculo (Gerente de palco, 01/10/2004).

Podemos observar que, apesar de haver a exigência de cumprimento dos prazos estabelecidos pela produção do espetáculo, o processo de trabalho na área técnica em artes e espetáculos não é totalmente estruturado, e as diversas equipes de apoio técnico têm de lidar permanentemente com situações de improviso, em que novas habilidades são requeridas de modo constante.

Nas montagens dos espetáculos do Theatro, são requeridas a responsabilidade e a autonomia desse trabalhador frente ao trabalho. Ao mesmo tempo, devido à escassez de tempo, cria-se uma forma de pressão e controle sobre os colegas. Como vimos na citação acima, o início de uma operação depende da finalização de outra. Observamos que é a partir da responsabilidade assumida por cada equipe de apoio técnico que se assegura o funcionamento de todo o conjunto (Ramos, 2002).

Outro desafio enfrentado pelos trabalhadores técnicos, que mobiliza seus saberes acumulados, é que - com as constantes mudanças nos focos das montagens, buscando atender a uma grande variedade de espetáculos - cabe aos técnicos conviver com os constantes problemas apresentados pelos cenários e adereços, os quais, devido à escassez de tempo ou falta de experiência da empresa construtora, chegam ao Theatro sem acabamento final. Apesar de eles não poderem mudar a peça do cenário, criam meios diferentes para manipular a maquinaria. Mesmo que o técnico não compreenda o significado daquela obra-prima, ele tem uma sensibilidade adquirida pela própria experiência, o que lhe possibilita compreender o conjunto do projeto.

Durante as montagens, são abertos alguns canais que permitem ao cenotécnico vinculado ao Theatro, responsável pelas montagens, ter uma relativa autonomia para tomar decisões ou opinar sobre o que pode ser modificado para melhor se adaptar às 
condições físicas do Theatro, desde que não altere o projeto original de criação feito pelo cenógrafo.

É da responsabilidade dos profissionais das equipes de apoio técnico viabilizar o projeto criado pelo diretor, coreógrafo, cenógrafo, figurinista, iluminador e por outros profissionais. Segundo podemos ver, eles participam da confecção desse material:

Quando começa essa parte de confeccionar mesmo as coisas, a gente também participa para dar a experiência, não é? Às vezes, a pessoa idealiza uma coisa e, às vezes, é impraticável. Então, com a experiência da gente, a gente vai falando isso não vai dar... Então vai... A não ser que seja uma pessoa que já trabalha há muito tempo dentro do próprio teatro, essa coisa toda. [...] Aí a gente faz um desenho técnico disso que vai ser montado sempre desta forma, poucas adaptações a gente pode fazer, porque você não pode alterar a criação, você pode adaptar algumas coisas, mas a criação você tem que manter (Cenotécnica do Balé, 30/09/2005).

Como pudemos observar em alguns depoimentos, para assegurar o êxito das montagens, será mobilizado muito mais um conjunto de saberes individuais, obtidos com a experiência profissional, do que conhecimentos advindos do uso de tecnologia e equipamentos. Mas as habilidades individuais só encontrarão sentido no coletivo ou juntamente com o trabalho de outras pessoas. E, ao mesmo tempo, devido à escassez de tempo para realizar as montagens, os profissionais devem desenvolver seu trabalho buscando assegurar que todas as áreas, como as de iluminação, cenotécnica, sonoplastia, maquinária, guarda-roupa e contrarregragem, direcionem suas ações sempre se voltando a um projeto de trabalho coletivo -é essa a característica que dá identidade profissional a esse grupo. Esses trabalhadores fazem parte de um dos poucos grupos de técnicos de palco permanentes que ainda residem no interior de um teatro público na cidade de São Paulo.

Ratto (1999) ${ }^{7}$ ressalta os sentimentos que

${ }^{7}$ Gianni Ratto foi cenógrafo, figurinista, iluminador e diretor de teatro, formado em artes plásticas pelo Liceu Artístico de Gênova. Trabalhou em importantes teatros na Itália, e veio ao Brasil em 1954, passando a trabalhar nos mais importantes teatros, inclusive no Municipal. Teve papel fundamental na formação de profissionais brasileiros na área artística e técnica. devem permear a postura de trabalho adotada pelos trabalhadores da área técnica, conforme expõe:

Honestidade, porque vocês vão se empenhar até o fim numa tarefa que exige competência, humildade e senso de coletividade; orgulho, porque vocês devem ter consciência do que estão fazendo, sabendo que são os colaboradores de uma obra coletiva dirigida para uma outra coletividade que, integrada à primeira, resulta num ato político. (1999, p.129).

De um lado, os técnicos devem atender à Instituição, representada nas figuras da direção artística, coordenação de cenotécnica e chefias diretas e indiretas, combinando uma forma de gerir o trabalho com o equipamento institucional disponível; de outro, têm o compromisso com o resultado do que será apresentado ao público. Nesse sentido, eles contribuem para dar concretude àquela obra de arte.

Conforme constatamos, o trabalho na área teatral tem suas especificidades em relação a outros do campo da produção cultural. Para compreender a importância de cada uma dessas peculiaridades na composição de um trabalho coletivo, fazemos abaixo uma breve descrição do funcionamento dos vários ofícios mais manuais da área de apoio técnico, vinculados ao Theatro Municipal.

O trabalho do cenotécnico pode ser concebido de várias formas, já que engloba a execução do cenário, como é o caso do cenotécnico contratado por projeto individual para viabilizar a criação do cenógrafo, quanto pode se referir ao profissional mais voltado para as atividades específicas da área teatral. Nesse último caso, ele é o responsável pela montagem do cenário no palco e também por todos os aspectos que envolvem a estética da caixa cênica. O cenotécnico é o executor da cenografia; e o maquinista é o operador da cenotecnia.

É necessário compreender também o trabalho da equipe de contrarregragem que, na ocasião de uma ópera, tem de trabalhar em todas as etapas e acompanhar os ensaios em todos os horários. Todos têm de se ajudar, pois se trata de um trabalho bastante coletivo. Durante o espetáculo, o contrarregra e sua equipe ficam na coxia observan- 
do a movimentação de cena, já que devem separar previamente todos os adereços pela ordem dos atos.

Antes do primeiro ensaio, o diretor e o assistente de direção já dizem o que vão querer em cena, por exemplo, uma mesa, uma faca. No ensaio, até podem usar adereço provisório, mas depois tem que ser substituído pelo original. Às vezes, o diretor esquece-se de falar de tudo o que vai ser utilizado, aí, pelo movimento do artista em cena, a gente deduz que faltará algum objeto, e pergunta: 'neste gesto, vai precisar de tal coisa?'. Os objetos pequenos, que vão na roupa do artista, como um canivete, dinheiro, a contrarregragem já deixa no camarim do ator. Depois, temos que conferir se ele porta o objeto em cena, temos que conferir tudo. Nas apresentações de ópera, além das observações visuais, existem as de ouvido; é pela música que sabemos qual é o momento de levar um adereço ou levantar a cortina, fazer o efeito do barulho ou da fumaça (Contrarregra, 09/09/2004)

No caso das camareiras, na ocorrência de um evento interno, elas entram como costureiras para ajudar na confecção dos figurinos. E quando vem uma produção de fora, com o cenário e a vestimenta prontos, as costureiras realizam o trabalho de camareiras, atendendo os camarins e os pedidos dos artistas, auxiliando-os na vestimenta e nos consertos de última hora. E, como rotina diária, elas fazem o trabalho de conservação dos figurinos. O Coordenador de Cenotécnica do Theatro (28/09/2006) expõe sua importância e especificidade:

É uma costureira específica para teatro, não é qualquer costureira, aquela costureira que faz ali um vestido, que costura ali na esquina; não é exatamente isso, tem que ter uma pessoa de teatro, que tem o corte, que tem o caimento, que tem que fazer um vestido de época, então é uma pessoa já também específica para a área teatral.

Apesar de o trabalho das costureiras ter de atender a essa especificidade, ele também é flexibilizado para atender a outras demandas internas do próprio Theatro:

Mesmo, então, serviço do palco, nós não trabalhamos só para isso. Cortina lá do palco, o pessoal nosso é chamado, a gente vai lá costurar. É tudo, capa de piano, quando precisa, é tudo, tudo, tudo. Eu tenho... Inclusive, as que trabalham de camareira, a gente pega costureira mesmo... Porque, na hora de fazer serviço de camareira mesmo, muita coisa arrebenta, alguma coisa, precisa saber. Precisa saber costurar, porque, muitas vezes, arrebenta um zíper, tem que trocar. (Chefe do guarda-roupa, 16/09/2004).

Ressaltamos que, em relação aos trabalhos de montagem no palco, como o dos maquinistas, de cenotécnica, de contrarregragem e também de confecção de figurinos e adereços, em que o trabalho é mais manual, mesmo utilizando-se de instrumentos de trabalho mecanizados, o saber-fazer dos técnicos de palco é indispensável nessas atividades.

Apesar de os técnicos de palco não aparecerem em cena, eles estão atuando em todos os momentos do espetáculo, lidam com um conjunto de expectativas, desde as suas próprias expectativas pessoais e dos seus colegas de equipe, até as dos diretores e produtores, estendendo-se às expectativas do público, que é o grande alvo a ser atingido. Esses profissionais têm uma relação direta com o resultado dos projetos de criação que serão apresentados ao público, que prestigiará ou não aquele trabalho.

Observamos que o desenvolvimento do trabalho desses profissionais ligados à área da cultura é limitado pela escassez de tempo e pela falta de recursos humanos e financeiros, mas, ainda assim, eles buscam superar esses limites e assegurar que o objeto de seu trabalho esteja disponível para a apreciação do público. Essa preocupação pode ser observada no depoimento da cenotécnica do Balé da Cidade:

O problema é quando você vai para um espaço que é pequeno ou que é mediano, ou que não tem gente... E aí você nem tem técnico específico para trabalhar nisso, porque lá são pessoas que cuidam de manutenção, que cuidam de outras coisas no ginásio, porque ali não é um teatro. Você conta com a boa vontade da pessoa e tem que dizer como é que vai ter que fazer para aquele espaço se transformar do nada em palco. Ver o resultado da coisa. É juntar as forças para fazer acontecer e, às vezes, dá bons resultados, e aí é gratificante. Você consegue transformar e dar oportunidade para que as pessoas assistam alguma coisa que elas não têm oportunidade de acompanhar sempre, essa é a vitória que a gente tem de encarar, de novo outra dessa... Na verdade, seria para estar saindo de um lugar todo cheio de 
apoio para outro, mas, durante muitos anos, desde que eu me conheço por gente aqui, a gente abriu mão e se faz em vários espaços, praças e tudo, para dar oportunidade das pessoas assistirem e conhecerem (Cenotécnica do Balé, 30/09/2005).

A cenotécnica demonstra a preocupação em ampliar os espaços de divulgação dessa concepção de cultura, mobilizando todos os esforços no sentido de atender a essas demandas. Quando a cenotécnica utiliza a expressão “a gente abriu mão”, fica implícito que ela está incorporando outros trabalhadores técnicos em sua fala, já que esse é um trabalho coletivo. Ficou claro que há um forte envolvimento com a realização do trabalho na área técnica, o que vai muito além das relações de trabalho estabelecidas com a instituição. Essa preocupação parece decorrer da própria relação que esse trabalhador constrói com o seu ofício, pois é através dos espaços de divulgação da obra de arte que ele obtém o reconhecimento social de seu trabalho.

Nesse sentido, a atuação do profissional técnico de apoio aos espetáculos é impulsionada a desenvolver um dinamismo imposto pelas próprias características do trabalho (Ramos, 2002). Podemos notar que tal trabalho traz uma mistura de saberes tradicionais da cultura com saberes advindos do uso de tecnologia, que são adquiridos fora daquele espaço de trabalho e por iniciativa própria do trabalhador, como são os casos da busca por cursos na área de sonoplastia e iluminação. Isso é confirmado pelo depoimento do sonoplasta do Balé da Cidade (23/11/2006):

Na área da dança, foi na prática mesmo, a pessoa, o coreógrafo mostrando pra mim tudo, o nome do ato, o movimento da posição que o bailarino fazia e eu fui aprendendo no dia a dia, aprendendo, porque eu, em dança, sabia, assim, só o acompanhamento das aulas que eram básicas, iniciação à dança moderna. Aqui não, aqui é uma companhia profissional que eu tive que... Até a parte de sonorização. Eu faço sempre cursos para poder sempre estar atualizado na parte técnica, não é? Agora, a área de dança foi nos ensaios que eu fui aprendendo como são a nomenclatura, os movimentos para poder soltar o som na hora certa.

Segundo Ratto, na área de teatro, a tecnologia pode contribuir com o processo de criação, mas não pode ser decisiva nesse processo, pois ela deverá sempre ser um meio e não um fim. "Não se deixe seduzir pela tecnologia: ela é fascinante, mas escraviza, limita sua criatividade, pois ficará permanentemente submetida aos cânones de estruturas e mecanismos não modificáveis.” (Ratto, 1999, p.89).

Tratando ainda das especificidades do trabalho nessa área, podemos destacar a importância do trabalho do técnico em iluminação para o espetáculo, considerando que a luz serve para iluminar alguns pontos que devem ser destacados no palco, mas, sobretudo, desempenha outro papel fundamental:

Às vezes, o tempo que uma cena entra, ela tem que estar muito ligada com a intenção do diretor, o tempo que aquilo acontece. [...]. Então, às vezes, você precisa colaborar com isso; nesse ponto que ela ajuda a direção, a direção do ator, direção mesmo. Ela está muito próxima do diretor de cena, a iluminação e a direção muito próximas; você consegue aplausos ou não. [...] Se você consegue fazer com a luz, segurar a luz apagada e aumentar nessa hora, você despeja o aplauso inteiro em cima do maestro. Então, você consegue ajudar o maestro ou atrapalhar muito; se você hesita nessa luz, a platéia acha que a luz vai apagar de novo, ou que alguma coisa vai acontecer e eles não aplaudem. E você, na luz, você faz ou não muito mais do que eles estão imaginando, você consegue subir a plateia (Técnico em iluminação, 26/11/2004).

A operadora de iluminação do Balé da Cidade de São Paulo descreve um pouco da organização do seu processo de trabalho. Segundo ela, o iluminador é o profissional que vai criar a luz. É a partir das inúmeras concepções de criação, envolvendo o diretor, o cenógrafo e o figurinista, que o iluminador, somando-se a elas, cria a iluminação do espetáculo. Assim, a criação da luz é sempre um trabalho em conjunto com outros profissionais.

Uma vez feita a criação da luz pelo iluminador, começa o trabalho do operador em iluminação. Conforme depoimento dessa profissional:

E aí, depois de tudo isso pronto, o iluminador faz um ensaio geral com todo mundo e passa para o operador. O iluminador não vai ficar operando a luz eternamente. Ele vai para o próximo trabalho, não é? E o operador de luz é o responsável para continuar o trabalho que o iluminador dei- 
xou. Então, o operador tem que saber trabalhar, ler o mapa de luz, saber ler o roteiro, saber o tempo, prestar atenção nas cenas e tudo e ter o feeling, que é para ter sensibilidade para saber trabalhar com mesa de luz, programação e tudo mais. Essa é a obrigação do operador. E, aqui no Brasil, também tem o técnico que faz as montagens, vai lá, pluga os cabos etc. É a parte braçal mesmo, que é instalar, colocar lá, puxar cabo de luz, sabe? É um serviço bem pesado. Então, minha obrigação é aprender tudo que o iluminador passar para mim. Tudo, ele passou o detalhe do tempo e tudo, eu repasso o que ele me passou. E, depois disso, eu tenho que fazer as adaptações no mapa, por exemplo, a gente está aqui no Theatro Municipal e a gente vai para o João Caetano, que é um teatro pequeno, eu tenho que saber fazer daquela coreografia, uma luz que não fuja da luz original, mas que caiba dentro daquele teatro. Então, eu vou pegar o material que o iluminador deixou pra mim e dar uma enxugada para virar uma adaptação. Então, tem todas essas coisas, assim, acabam ficando na minha função (Operadora de iluminação, 23/11/2006).

As mudanças técnicas, em algumas áreas como a da iluminação e do som, poderiam possibilitar uma maior programação das atividades, o que implicaria aumento da produtividade do trabalho na área técnica, abrindo espaço para uma maior padronização do trabalho, e isso poderia criar possibilidades de substituição dessa força de trabalho. Mas, por ser um trabalho desenvolvido em um teatro, em que há mobilização de outras esferas do conhecimento, possivelmente a substituição desses trabalhadores implicaria um empobrecimento desses espetáculos. Para o exercício das profissões de iluminador e sonoplasta voltadas ao campo teatral, faz-se necessário compreender a linguagem cênica dos espetáculos.

Além disso, o processo de trabalho de produção dos espetáculos - como, por exemplo, as montagens no Theatro Municipal - é marcado por situações de improviso, o que impediria a aplicação de métodos de trabalho padronizados, como usualmente se faz nos processos produtivos industriais, com o objetivo de exercer um controle direto sobre as ações dos trabalhadores.

Mas a possibilidade de o Theatro Municipal implementar o uso de uma tecnologia mais avançada em seu maquinário acabou se tornando uma realidade. No segundo semestre de 2008, fo- ram iniciadas reformas na fachada externa do prédio do Theatro, que tiveram continuidade em 2009, com a realização das obras internas. Apesar da previsão inicial de reabertura do Theatro para o ano de 2010, a reinauguração só pôde ocorrer em 10 de junho de 2011. Observamos que a citada reforma do Municipal não tratou apenas da preservação do patrimônio, como ocorreu em outros momentos, mas englobou a renovação de todo palco, substituindo a parte mecânica de montagem e a de iluminação por equipamentos mais automatizados.

Por outro lado, a ex-coordenadora de cenotécnica (25/09/2005), que ocupou esse cargo em fins dos anos de 1990, demonstrou preocupação com o reduzido número de técnicos que atendem às necessidades do teatro, e, como proposta para aumentar a produtividade, sugeriu uma ampliação das contratações nessa área. Segundo ela:

É infelizmente que nessa parte é difícil, não é? A maioria está com contrato [...] São poucos cargos atualmente que tem; deveria ter feito uma reestruturação já há muito tempo, principalmente no Theatro Municipal, que são poucos cargos; então, você trabalha com poucas pessoas, não é? Você tem que medir a programação que faz, você jamais poderia ser como são os teatros, fora que você monta uma coisa hoje e amanhã é outra, você não tem equipe para estar trabalhando; têm teatros aí fora que trabalham 24 horas, sai uma equipe diurna e entra a noturna. Então, você pode estar mudando a cenografia, um dia é a orquestra, outro dia tem uma ópera, outro dia tem um balé, aqui é inviável [...]

Conforme constatamos, o trabalho de apoio técnico tem por base o desenvolvimento de uma atividade criativa, mais ligada a um saber-fazer. Sem se vincular diretamente a uma tecnologia mais complexa, os técnicos de palco do Theatro sempre dispuseram de pouca tecnologia, e isso lhes dava maior autonomia para tomar decisões nas montagens, o que os levava a ter de adotar posturas mais independentes em relação aos equipamentos automatizados.

Entretanto, a alternativa para o aumento da produtividade da produção cultural do Theatro não priorizou o saber-fazer específico desse ofício, mas optou pela implementação de uma tecnologia 
mais avançada no uso de seu maquinário. Assim, nessa perspectiva, podemos retomar as afirmações de Marx (2004) de que são os meios de produção, na qualidade de modo de existência do sistema capitalista, que se contrapõem ao trabalho e aparecem também fora do processo de produção, potencialmente como modo de existência específico do capital. Portanto, essas reflexões nos ajudam a compreender o papel que a automação poderá desempenhar nesse contexto de alteração dos contratos de trabalho, devido à mudança do estatuto do Theatro Municipal de instituição pública para o de fundação de direito público. Para Marx, no processo de trabalho, há uma contradição, pois as condições objetivas do trabalho (meios de produção) se contrapõem às condições subjetivas (capacidade de trabalho). Na realidade, são os meios de produção que funcionam como meios de sucção de maior quantidade de trabalho vivo, propiciando a extração de uma maior taxa de mais-valia. Nesse sentido, a automação poderá intensificar o processo em curso de racionalização econômica do trabalho na área de apoio técnico do Municipal.

A inserção de maior automação no trabalho técnico, no sentido de incorporar uma maior parte do trabalho dos técnicos de palco nas máquinas, tem expropriado esses trabalhadores de seu conhecimento e domínio sobre o processo de produção dos espetáculos, fragilizando-os na negociação para a transferência de seus contratos de trabalho para a Fundação do Theatro, gerida por uma Organização Social (OS). Essa renovação tecnológica implicou a necessidade de os técnicos do teatro se adaptarem aos novos procedimentos, desestimulando-os a se manterem naquele teatro e fazendo com que se sentissem incapazes de reelaborar o seu saber-fazer frente às novas demandas da Instituição.

É importante ressaltar que essas mudanças recentes ocorridas no Theatro vêm carregadas de contradições, pois, durante quase três anos de seu fechamento, houve paralisação das atividades artísticas. Além disso, o cargo de direção artística do Theatro ficou vago entre 2009 e 2010, situação que se repetiu também no início de 2011. Durante esse período, não houve os tradicionais concertos e as

temporadas de óperas, sendo um momento marcado por muita desmobilização por parte dos técnicos e dos músicos (Pichoneri, 2011), impedidos de desenvolver seu trabalho, e, portanto, privados de refletir coletivamente sobre as futuras mudanças. E justamente foi durante esse período de fechamento do teatro que foi sendo gestado o desenho de criação da Fundação Theatro Municipal de São Paulo, aprovada pela Câmara Municipal em 2011 e implementada em 2013.

\section{CONSIDERAÇÕES FINAIS}

Os resultados do nosso estudo revelam que tem havido redução dos vínculos contratuais estáveis, expansão das formas temporárias de trabalho e precarização do trabalho dos técnicos de palco do Theatro Municipal de São Paulo, processo que tem se intensificado a partir dos anos 1990, no bojo da flexibilização e desregulação do trabalho nos setores público e privado no Brasil.

O processo de mudanças nas formas de regulamentação do trabalho dos técnicos de palco inicia-se já na década de 1980, momento em que se passou a observar a seguinte contradição: ao mesmo tempo em que houve a ampliação do número de cargos na área de apoio técnico aos espetáculos, também ocorreu a perda da estabilidade no emprego para a grande maioria destes trabalhadores, já que, anteriormente, eles eram contratados através de vínculos estáveis de trabalho. A partir de 1981, o Theatro Municipal elimina os mecanismos legais para a realização de concurso público para inserção nessa área. A maior parte dos cargos residuais estáveis continuou sendo progressivamente extinta por ocasião das aposentadorias, transferências para outros setores ou demissão, passando a haver apenas reposição parcial desses técnicos, sendo que os novos passaram a se inserir em cargos em comissão ou outra forma mais precária.

Esse novo estatuto não garantiu estabilidade no emprego, pois os técnicos poderiam ser exonerados a qualquer momento. Assim, ampliaram-se os mecanismos de contratação com vínculos precá- 
rios. Além disso, observamos que a partir dos anos de 1990, não ocorreram novas contratações, com consequente redução dos membros das equipes de apoio técnico.

Além do quadro descrito acima, notamos que, no final da década de 1990, como forma de redução de custos relativos à contratação de pessoal, houve estímulo para a ampliação das formas de terceirização dos trabalhos relativos à criação e confecção dos figurinos, cenários e adereços, passando-se a priorizar as formas de contratação por projetos, já que, dessa forma, o Theatro Municipal não necessitaria ampliar seu quadro de profissionais permanentes. Esse mecanismo permitiu à referida instituição transferir a responsabilidade da contratação e manutenção de profissionais dessa área para os ateliês particulares. Nesse sistema, a permanência de todos os envolvidos no processo de produção e realização dos espetáculos se encerrava juntamente com o fim das temporadas, e ao Theatro coube manter apenas as equipes que serviam de apoio técnico às montagens dos espetáculos.

Observamos que, até a década de 2010, o Theatro Municipal de São Paulo adotava três formas de contratação de trabalhadores na área técnica: a primeira delas na condição de cargo em comissão, a segunda através da prestação de serviços por intermédio de "Verba de Terceiros" com contratos renovados a cada 6 meses, e a última forma os contratos temporários para as temporadas de óperas.

No contexto das formas de regulação do trabalho estabelecidas pelo Theatro Municipal de São Paulo, a grande maioria dos profissionais da área técnica estava inserida na condição de cargos em comissão, tendo por base contratos de trabalho que não possibilitavam estabilidade no emprego. Essa era a relação formal existente entre a instituição e esses trabalhadores, na qual não se colocava a necessidade de ter uma formação profissional com conteúdo específico para o exercício da profissão. Mas, apesar disso, na prática profissional desses trabalhadores, era solicitado muito mais que o simples desempenho de suas funções. Exigia-se que houvesse um comprometimento com um saber-fa- zer próprio de um ofício artesanal, e eles deveriam ser portadores de habilidades e de conhecimentos específicos. Além disso, no caso de implementação de uma maior automação no processo de trabalho, eles deveriam se adaptar às novas circunstâncias.

Somadas a essas questões, observamos que, a partir da década de 1990, houve mudanças nas formas de financiamento público da cultura, nas quais se insere a produção cultural do Theatro Municipal, passando-se a priorizar a captação de recursos na iniciativa privada. Nesse novo contexto, a produção dos espetáculos passou a adotar práticas que modificaram a composição básica ou tradicional das profissões que integram esse processo de trabalho, fazendo com que os ofícios de caráter mais especificamente manuais e técnicos se tornassem cada vez menos valorizados.

Nesse sentido, podemos observar que a regulamentação do trabalho no campo da produção cultural segue a tendência predominante na iniciativa privada, em que o trabalho por tempo indeterminado está perdendo hegemonia. Surgem novas relações contratuais, que vêm marcadas pela flexibilidade, atuando no sentido de criar uma força de trabalho flexível, que atenda às novas demandas do campo da produção cultural. Desse modo, é cada vez mais crescente o número de contratos de trabalho por tempo determinado, muitas vezes sem registro em carteira, levando um crescente número de trabalhadores para a informalidade.

Assim, verificamos que a manutenção de uma equipe permanente reduzida e sem garantia de estabilidade no emprego tem sido uma prática adotada pela Administração Pública. Sendo o Theatro Municipal de São Paulo um órgão público que se insere em uma sociedade regida pela economia de mercado, ele submete suas decisões às mudanças direcionadas pelo mercado e, nesse sentido, quanto menos estáveis e duradouras forem as relações salariais estabelecidas na área da cultura, maior será seu poder de decisão sobre extinguir o vínculo estabelecido com os profissionais da área de apoio técnico. Ressaltamos ainda que as formas de regulamentação desses contratos sofreram alterações com a implementação da Fun- 
dação do Theatro Municipal em 2013.

Portanto, o Theatro Municipal tem adotado medidas que têm levado à alteração das políticas internas de organização dos espetáculos e, consequentemente, afetado, de modo direto, as formas de contratação dos profissionais técnicos de apoio aos espetáculos, que estão submetidos à falta de vínculos estáveis e também às indefinições políticas que permeiam as várias gestões do poder público. Na prática, o desenvolvimento das atividades artísticas torna-se dependente da disponibilidade de recursos públicos ou privados e, a partir deles, é que se definem as formas de redução ou ampliação das equipes internas e da terceirização parcial desses trabalhos. Por outro lado, a instituição não tem uma estrutura organizacional interna que possa corresponder às novas demandas geradas no mercado da produção cultural, sendo a falta de investimentos nas carreiras dos profissionais da área técnica um exemplo disso.

Nesse sentido, os grandes desafios e expectativas por parte da gestão pública em sanar os problemas estruturais do Theatro, relativos a uma maior racionalidade no processo de produção cultural - o que inclui alteração de critérios para a contratação de pessoal, capacitação de trabalhadores para o exercício da função, captação de recursos financeiros e outras -, têm sido transferidos para a Fundação Theatro Municipal de São Paulo, implementada em 2013. ${ }^{8}$

Recebido para publicação em 09 de setembro de 2012 Aceito em 12 de março de 2013

\section{REFERÊNCIAS}

ALVES, Maria Aparecida. Políticas públicas de cultura e o trabalho técnico no campo da produção cultural. Curitiba Editora Appris, 2012.

"Setor informal" ou trabalho informal? uma abordagem crítica sobre o conceito de informalidade. 2001. 157 f. Dissertação (Mestrado em Sociologia) - Programa de Pós-Graduação em Sociologia da Universidade Estadual de Campinas-SP. 2001.

8 Esta pesquisa recebeu apoio financeiro no período de 2004 a 2007, através de bolsa de doutorado concedida pela CAPES - Coordenação de aperfeiçoamento de Pessoal de Nível Superior.
ANTUNES, Ricardo. (Org.) Riqueza e miséria do trabalho no Brasil. São Paulo: Boitempo Editorial, 2006.

ABRAMO, Lélia. Vida e arte. São Paulo: Campinas: Fundação Perseu Abramo; Ed. UNICAMP, 1997.

BELARDI, Armando. Vocação e arte: memórias de uma vida para a música. São Paulo: Edição Manon, 1986.

BERNARDES, Maria Elena. Estandarte glorioso da cidade: Teatro Municipal de São Paulo - 1911-1938. 2004. 318 f. Tese (Doutorado em História). Programa de Pós Graduação em História da Universidade Estadual de Campinas. 2004

BRANDÃO, Ignácio de Loyola. Teatro Municipal de São Paulo - grandes momentos. São Paulo: DBA Artes e Gráficas, 1993

CACCIAMALI, M. C. Globalização e processo de informalidade. Economia e Sociedade, Campinas, Instituto de Economia da UNICAMP, n.14, p.152-174, jun, 2000.

CASTEL, Robert. As metamorfoses da questão social. Uma crônica do salário. Rio de Janeiro: Vozes, 1998.

COLI, Juliana Marília. Vissi D’Arte por amor a uma profissão (um estudo sobre a profissão do cantor no Teatro Lírico). São Paulo: Annablume, 2006.

DEDECCA, Claudio S. Racionalização econômica e trabalho no capitalismo avançado. Campinas: Instituto de Economia da UNICAMP, 1999.

FERRARA, J. A.; SERRONI, J. C. (Org.) 16 anos de cenografia e indumentária 1948/64. São Paulo: Secretaria de Estado da Cultura, 1980.

HARVEY, David. A condição pós-moderna. Uma pesquisa sobre a origem da mudança cultural. São Paulo: Loyola, 1993.

MACHADO. Lucília R. S. Qualificação do trabalho e relações sociais. In: FIDALGO, F.S. (Org.) Gestão do trabalho e formação do trabalhador. Belo Horizonte: Movimento de Cultura Marxista, 1996. p.12-40.

MAGALDI, Sábato. Teatro sempre. São Paulo: Perspectiva, 2006.

Depois do espetáculo. São Paulo: Perspectiva, 2003.

MARX, Karl. XII Divisão do trabalho e manufatura. In O capital - crítica da economia política. 7.ed. Trad de Reginaldo Sant'Anna. São Paulo: Difel, 1982. v.1 p.386422 (Livro 1: O processo de produção do capital).

Capítulo VI Inédito de O Capital. Resultados do processo de produção imediata. 2.ed. Trad. Klaus Von Puchen. São Paulo: Centauro, 2004.

MATTOS, David José Lessa. O espetáculo da cultura paulista: teatro e televisão em São Paulo (décadas de 1940 e 1950). São Paulo: Codéx, 2002.

MENGER, Pierre-Michel. Retrato do artista enquanto trabalhador. Metamorfoses do capitalismo. Lisboa: Roma Editora, 2005

PICHONERI, Dilma Fabri Marão. Relações de trabalho em música: o contraponto da harmonia. 2011. 218p. Tese (Doutorado em Educação) - Programa de Pós-Graduação em Educação da Universidade Estadual de Campinas. 2011.

PREFEITURA DO MUNICÍPIO DE SÃO PAULO. O poder em São Paulo: história da administração pública da cidade 1554-1992. São Paulo: Cortez, 1992.

RAMOS, Marise N. A pedagogia das competências: autonomia ou adaptação? 2.ed. São Paulo: Cortez , 2002.

RATTO, Gianni. Antitratado de cenografia: variações sobre o mesmo tema. São Paulo: Editora SENAC, 1999.

RUBIM, Antonio A. C.; BARBALHO, Alexandre (Org.) Políticas culturais no Brasil. Salvador: EDUFBA, 2007. 
SALVADORI, Maria Angela B. Memória, cultura e cidadania: estudo de uma política pública. 2000. 267 p. Tese (Doutorado em Educação) - Programa de Pós-graduação da Faculdade de Educação da Universidade Estadual de Campinas. 2000.

SARAIVA, Hamilton Figueiredo. Iluminação teatral: historia, estética e técnica. 1989. Dissertação (Mestrado em Artes) - Programa de Pós-graduação da Escola de Comunicações e Artes da Universidade de São Paulo. 1989.

Estrelas da coxia. Sonoplastas e iluminadores entram em cena para mostrar que o espetáculo não existiria sem eles. Revista e São Paulo, v.3, n.10, p.23-24, 1997.

SEGNINI, Liliana R. P. Acordes dissonantes: assalariamento e relações de gênero em orquestras. In: ANTUNES, R. (Org.). Riqueza e miséria do trabalho no Brasil. São Paulo: Boitempo Editorial, 2006. p.321-336.
SENNETT, Richard. A corrosão do caráter. 4.ed. Trad. Marcos Santarrita. Rio de Janeiro; São Paulo: Ed. Record, 2000 SERRONI, José C. Teatros uma memória do espaço cênico no Brasil. São Paulo: Ed. SENAC, 2001.

TOMASI, Antônio P. N.; SILVA, Ivone M. M. Ofícios de ontem e ofícios de hoje: ruptura ou continuidade? In: CONGRESSO BRASILEIRO DE SOCIOLOGIA,13., 2007, Recife. Anais... Recife: UFPE.

WILLIAMS, Raymond. Cultura. 2.ed. Trad. Lólio L. de Oliveira, Rio de Janeiro: Paz e Terra, 2000.

WU, Chin-tao. Privatização da cultura: a intervenção corporativa na arte desde os anos 1980. Trad. Paulo Cezar Castanheira. São Paulo: Boitempo, 2006.

YÚDICE, George. A conveniência da cultura - usos da cultura na era global. Belo Horizonte: Editora UFMG, 2006. 


\section{REGULATION AND ORGANIZATION OF STAGE TECHNICIANS' WORK IN THE FIELD OF CULTURAL PRODUCTION}

\section{Maria Aparecida Alves}

The objective of this paper is to analyze the forms of hiring and labor regulation of the stage technicians linked to the Municipal Theatre of Sã̃o Paulo, as well as the ways of organizing that process of labor, which includes various forms of spectacles. The technical teams are composed of professionals in the areas of production, lighting, stage, machinery, sound, wardrobe and ornaments. Methodologically, the study is based on qualitative research, focusing on open and in-depth interviews and field observation. The construction of the empirical data of the research came from the oral testimonies of the workers in the area of technical support, of their direct managers and of other professionals, which were corroborated by documentary and bibliographical research in libraries, research centers and government agencies. Results of the study show that there was reduction of stable contractual relationships, and expansion of temporary and precarious forms of employment in the technical area of the theatre.

KEYWoRDS: technical labor, labor relationship, precarious labor, labor organization.

\section{LA REGLEMENTATION ET L'ORGANISATION DU TRAVAIL DES TECHNICIENS DE SCENE DANS LE DOMAINE DE LA PRODUCTION CULTURELLE}

\author{
Maria Aparecida Alves
}

L'objectif de cet article est d'analyser les formes de contrats et de régulation du travail des techniciens de la scène liées au Théâtre Municipal de São Paulo, ainsi que les moyens d'organiser du processus de travail, qui englobe diverses modalités de spectacles. Les équipes techniques sont composées de professionnels dans les domaines de la production, de la lumière, de la scénotechnique, des machines, du son, des costumes et contre-regragem. Méthodologiquement, l'étude est basée sur une recherche qualitative qui privilégie des entretiens ouverts et approfondis et des observations de champ. La construction de la recherche empirique vient du témoignage oral des travailleurs dans le domaine de l'assistance technique, leurs responsables directs et d'autres professionnels, qui ont été corroborées par des recherches documentaires et bibliographiques dans les bibliothèques, les centres de recherche et les organes publics. Les résultats de l'étude montrent que l'espace de travail il n'y a quasiment pas de liens stables en ce qui concerne l'embauche, les techniciens occupent des postes de emploi précaire, et le sous-emploi dans le domaine technique.

Mots-Cles: Le travail technique, la relation de travail, la précarisation, l'organisation du travail.

Maria Aparecida Alves - Doutora em Educação pela Universidade Estadual de Campinas. Professora adjunta da Universidade Federal Fluminense, no Instituto de Educação de Angra dos Reis. Atua principalmente nos temas: políticas públicas de cultura, sociologia da cultura, sociologia da educação, sociologia do trabalho e temas relativos à informalidade e precarização do trabalho, educação e trabalho, formação profissional. Publicações recentes: Políticas públicas de cultura e o trabalho técnico no campo da produção cultural. Curitiba: Editora Appris, 2012, 265p.; As implicações das leis de incentivo à cultura sobre o processo de produção dos espetáculos no Theatro Municipal de São Paulo. Estudos de Sociologia (São Paulo), v. 16, p. 161175, 2011; Reflexos das políticas no campo da produção cultural: um olhar a partir do Theatro Municipal de São Paulo. Extraprensa (USP), v. I, p. 214-225, 2010; O trabalho de técnicos de palco no contexto de um teatro público: décadas de 1950 a 2000. Proa: Revista de Antropologia e Arte, v. 1, p. 1-29, 2009. 